\title{
Annual Meeting of the American Historical Association
}

\author{
David Bensman
}

Rutgers University

Michael Musuraca

CUNY

Anson Rabinbach

Cooper Union

The 1985 annual meeting of the American Historical Association was held from December 27-30 in New York City. This report is on nine sessions dealing with themes of interest to the readers of this journal. For a catalogue of the meeting, which had additional panels with a labor history component, write to the American Historical Association, 400 A Street SE, Washington, DC, 20003.

The most unusual features of the annual meeting were the two joint meetings between historians and members of the Industrial Relations Research Association. As David Brody indicated, these two disciplines have rarely conversed, because industrial relations has based itself on a "systems" approach that emphasizes stability over change. This attempt to stimulate a new dialogue aroused considerable interest.

The first of the two sessions took an unusual tack: Melvyn Dubofsky (SUNY, Binghamton) compared industrial relations in the 1920 s with the 1980 s, while Irving Bernstein (UCLA) compared the 1930s with the 1960s. Dubofsky found many similarities in the two periods, particularly in the fact that employers crushed unions on the one hand, and preached cooperation on the other. Bernstein showed how the welfare state measures of the New Deal era were broadened during the Great Society, albeit on a more fragile political foundation. Unfortunately, the comparative approach did not clarify why the collective bargaining system that emerged with the New Deal has begun to break down.

The second session, a roundtable on theories of industrial relations and labor history, was also disappointing. David Brody suggested that labor history's search for a synthesis, and industrial relations' current attempt to explain recent changes in the collective bargaining system, may make for a convergence. Brody suggested that Piore and Sabel's recent book, The Second Industrial Divide, might provide a starting point for exploring common ground. Robert Ozanne (Wisconsin) did not seem sympathetic to the session's 
theme, however. Ozanne denied that industrial relations had a theory, and asserted that historians have had no influence on the field of industrial relations. Historians, he said, should keep to their old-fashioned job, presenting a nostalgic view of the past. He also decried the ideological motivation of some of the recent labor history. Nick Salvatore (Cornell) seemed to join this critique, asserting that "the new labor history" assumes that class exists and doesn't sufficiently distinguish between class as an institution, class formation, and consciousness of class formation. Ronald Schatz (Wesleyan) and Robert Zieger (Wayne State) had some interesting things to say about the corporatist strain in industrial relations theory and the anomalously marginal position of labor history in America, but their contributions were overshadowed by the ideological controversy unleashed by their fellow discussants.

Perhaps the joint sessions would have been more fruitful if they had focused on the recent scholarship of industrial relations theorists like Thomas Kochan and Harry Katz, who have written their own historical sketches of the collective bargaining system of the 1930s-70s, in order to explain why a new system is emerging today, one based, they believe, on flexible manufacturing, educated workers, international competition, and labor-management cooperation.

Historians also took on new and important issues in a session entitled "The Vicissitudes of Capital: Job Loss and Capital Mobility in an Industrial City, Philadelphia, 1865-1936." Phillip Scranton (Rutgers, Camden) looked at the deindustrialization of one city, focussing on the closing of inner-city textile mills and the growth of suburban manufacturing establishments. Walter Licht's study on "Losing Work in Philadelphia" examined the personnel records of two firms and suggested that "the very vicissitudes of the economy made job stability an exceptional experience." These papers suffered from a lack of historical context. Scranton and Licht (Pennsylvania) indicated that their presentations were pieces of a much larger study of Philadelphia labor and industry.

A fourth panel centered on George Frederickson's study of "Intellectuals and the Labor Question in Late Nineteenth-Century America." Frederickson (Stanford) raised an interesting comparative question: Why is it that in England, intellectuals critical of industrial capitalism and sympathetic to labor were able to develop a working relationship with trade unions culminating in the development of the Labour party, while in America, intellectual critics of industrial capitalism failed to establish such a relationship? Frederickson's analysis of the development of pro-labor, anti-capitalist attitudes among "social Christian" intellectuals was helpful for reminding labor historians that the Gilded Age labor struggles occurred during a period of great cultural uncertainty and change. Frederickson argued that while many intellectual critics of the emerging industrial order sympathized with workers' protests and admired the ideology of the Knights of Labor, they were repelled by the violence and threats to social order represented by the workers' strikes and boycotts. This is 
not surprising, Frederickson argues: The social Christians' anti-capitalism was embedded in a philosophy of organic nationalism in which the well-being of the state and the maintenance of social order were more important than the immediate eradication of social injustice. Frederickson promised a more detailed analysis of the intellectuals' reaction to specific strikes when he completes his larger study.

All three of the historical ventures summarized above were path-breaking ventures, limited by the fact that they were not fully developed. More satisfying were two panels on Mexican-American workers and on Women and Office Work.

Camille Guerin-Gonzales's (U-Calif., Riverside) paper on "The International Migration of Mexican Workers" concentrated on the recruitment of Mexican workers by California planters in the early years of the twentieth century and the methods used by the planters to insure themselves a docile work force. The recruitment of Mexican workers began in 1900, when immigration from Europe and Asia was falling. Growers viewed newly arrived Mexicans as a source of cheap labor who could be separated from American workers and who would return home after the harvest.

Growers controlled their labor force by recruiting workers from a variety of immigrant groups which were kept in constant competition. Still, by 1920, Mexicans constituted the largest ethnic group in California agriculture. Planters controlled them by overrecruiting workers and by fostering a constant fear of deportation. During the Great Depression, planters used the Mexicans as scapegoats for the mass unemployment, and 500,000 workers returned to Mexico.

Zaragosa Vargas's paper examined the experience of Mexican workers employed at Ford Motor Co. in the 1920s. Through an examination of personnel department records, Vargas (Yale) found that the vast majority of Ford's Mexican workers had previous industrial experience. They had worked in skilled, semiskilled, and unskilled industrial jobs, and their experience at Ford was similarly varied. Indeed, Vargas reports, Mexican workers fared better at Fords' River Rouge plant than did black workers. While both groups worked under brutal conditions and contracted numerous occupational diseases, Mexican workers held a greater variety of jobs than did blacks, who were segregated in the foundry. Furthermore, Mexican workers were mobile; like birds of passage they followed industrial jobs from city to city throughout the Midwest, and found employment in all 110 of Detroit's auto factories.

Another session, on "Office Work and Office Workers in the United States, 1870-1965" was also successful. Lisa Fine's study of the making of a female clerical labor force in Chicago argued that women workers created their own institutions and culture as they entered the clerical profession. Using records from women's business schools and clubs, Fine (Michigan State) analyzed rituals that expressed both the women's ambivalence towards love and family, and their growing pride in careers that were gaining social legitimacy. Priscilla 
Murolo's study of the rationalization of clerical work at Aetna Life Insurance Company compared what happened when scientific management techniques were applied to jobs performed predominantly by men and those performed by women. In general, Murolo (Empire State) found that supervisors of male employees were able to thwart efforts at routinization but supervisors of women were unable to do so. Margaret Hedstrom's study, "Broken Promises: Electronic Computers and the Automation of Office Work, 1950-65," detailed the disappointments experienced by corporate managers hoping to reduce the size of their office work force. Only in the mid-1960s, when top management began to stress systems analysis over hardware, did computers begin to revolutionize the office, Hedstrom (Wisconsin) argued.

Rounding out this survey are reports on the popular front, the Viennese working class, and reformism in contemporary Europe.

The panel on the "Popular Front Experience" commemorated the fiftieth anniversary of the French popular front with a comparative analysis of the French, Spanish, and Chilean experiences. Most illuminating was Irwin Wall's "The French Popular Front: A Reconsideration," which argued against the consensus of historians that the popular front had failed because it did not pull France out of the depression and left France militarily unprepared. The right, Wall (U-California, Riverside) noted, is expected to govern, the left to succeed, a calculus weighted against the popular front government. In electoral terms the Blum government was a success, and new research shows that it did increase defense expenditures at the expense of social programs. The dilemmas of austerity vs. defense and social spending, electoral growth vs. movement solidity, were not unique to Blum, as the Mitterrand experience amply demonstrates. Santos Julia Diaz, of Madrid, focused more narrowly on the political origins of the popular front experience in Spain. He cited new archival discoveries that demonstrate that the Communists did not, as widely claimed, initially favor such a policy, and that in 1935 Largo Caballero invited the Communists into a coalition of Populists and Socialists in order to widen his own base of support and reduce the preeminence of the centrist faction among the Socialists. Carl A. Ross's (Appalachian State) assessment of the Chilean popular front experience amounted to an uncritical literature review, which argued that the conditions of the popular front experience in Chile were uniquely Chilean in nature and remote from European circumstances.

Moving from France to central Europe, there was a session on "Industrialization and the Working Class: The Viennese Example." Using data derived from statistical and oral history sources, Robert Wegs's provocative and wellargued “' 'Was it Really So Bad?' Industrialization and the Working Class Family in Vienna 1890-1930," called for a revisionist interpretation of the Viennese industrializing experience. Negative descriptions of extreme poverty and social disintegration, usually derived from the middle-class bias of the Socialists, he argued, were unsubstantiated. Most working-class families did not 
disintegrate, there were stronger familial ties, less patriarchal authority, and more cohesion and community than previously assumed. Commentator William H. Hubbard (Concordia) accused Wegs (Notre Dame) of "overkill" and of excessive claims to originality for a viewpoint common in other areas of European social history. Wegs infused his evidence with a different kind of middle-class bias (more permissive and liberal), ignored harder data on wages and unemployment, blurred sociological perspectives, and relied too heavily on oral techniques that had several built-in biases: age, sex, and the elusive aspects of memory. Louise Tilly (New School) added that women were overrepresented in the data and many of the conclusions were based exclusively on woman's perspective, for example, emphasis on making ends meet, and on survival. All agreed that the political dimension was missing.

The session "The Cultures of Reformism in Contemporary Europe" focussed on different dimensions of reform and cultural politics in Europe from the late 19th century to World War II. Anson Rabinbach's “Knowledge, Risk and the Politics of Industrial Accidents" analyzed how new forms of social knowledge-statistics, medicine, law, and fatigue research-were applied to the accident question in Germany and France. He argued that a new idea of "social risk" emerged around the debates on industrial accidents, and that state responsibility and compensatory policies for the negative effects of social life became a central issue. Knowledge was called upon to arbitrate disputes about social risk and responsibility, politicizing knowledge. Atina Grossmann's (Mount Holyoke) "Diversion and Rationalization: The 'New Woman' in Weimar Sex Reform" argued that during the Weimar period "rationalization" was not limited to the sphere of the factory, but was extended to the household. German sex-reformers, doctors and sociologists upheld the ideal of a "new woman" who combined wage labor, marriage and a family with an active sexuality. In this new image of woman, rationalization and the techniques of "Taylorism" applied to everyday life made it possible to juggle the double burden. In her "The Announcing of the Machine in the Garden: Americanism in the Recasting of European Market Culture, 1920-1945," Victoria de Grazia (Rutgers) focussed on mass culture and advertising in interwar Europe. She delineated a conflict, evident in the advertising design and among advertising professionals, between an emerging Americanized "culture of consumption" in which the consumer was socialized into a marketplace that transcended local or class bonds, and a more European style of consumerism that emphasized modernist symbolism and avant-garde techniques. Since the culture of consumerism preceded the mass market for goods in Europe, this conflict reflected conflicting assumptions about the market itself. Europeans adopted an elitist symbolic representation of "dynamic capitalism" in poster art, and resisted the domesticated "capitalist realism" of the American mass market advertising style. In his commentary Charles Maier (Harvard) noted the creative use of new source material in all three papers, and emphasized the common 
aspects of these divergent cultural responses to reform, the construction of the "sphere of the social." The idea of state intervention, socialized knowledge, domestic rationalization and commercial culture all involved different aspects of the modern promesse de bonheur, social welfare and domestic hedonism. These were new phenomena in the 1920s and 1930s, but they also eroded the public sphere of political debate and discourse which produced them. 